\title{
Application of Albumin-embedded Magnetic Nanoheaters for Release of Etoposide in Integrated Chemotherapy and Hyperthermia of U87-MG Glioma Cells
}

\author{
MELÁNIA BABINCOVÁ ${ }^{1}$, HANA VRBOVSKÁ ${ }^{1}$, PAUL SOURIVONG ${ }^{2}$, PETER BABINEC $^{1}$ and ŠTEFAN DURDÍK ${ }^{3}$ \\ ${ }^{1}$ Department of Nuclear Physics and Biophysics, Faculty of Mathematics, \\ Physics and Informatics, Comenius University, Bratislava, Slovakia; \\ ${ }^{2}$ Oklahoma Cancer Specialists and Research Institute, Tulsa, OK, U.S.A.; \\ ${ }^{3}$ Department of Surgical Oncology, Saint Elisabeth Cancer Institute and Faculty of Medicine, \\ Comenius University, Bratislava, Slovakia
}

\begin{abstract}
Background/Aim: Malignant gliomas remain refractory to several therapeutic approaches and the requirement for novel treatment modalities is critical to combat this disease. Etoposide is a topoisomerase-II inhibitor, which promotes DNA damage and apoptosis of cancer cells. In this study, we prepared albumin with embedded magnetic nanoparticles and etoposide for in vitro evaluation of combined hyperthermia and chemotherapy. Material and Methods: Magnetic nanoparticles were prepared by a modified co-precipitation method in the presence of human serum albumin and etoposide. A cellular proliferation assay was used to determine the effects of these nanostructures on the viability of U87 glioma cells in an alternating magnetic field. Results: The in vitro experiments showed that cell viability decreased to $59.4 \%$ after heat treatment alone and to $53.8 \%$ on that with free etoposide, while combined treatment resulted in $7.8 \%$ cell viability. Conclusion: Integrating hyperthermia and chemotherapy using albumin co-embedded magnetic nanoheaters and etoposide may represent a promising therapeutic option for glioblastoma.
\end{abstract}

Glioblastoma multiforme (GBM), an astrocytic glioma, is one of the most common malignant primary brain tumors, characterized by intense and aberrant vascularization and

Correspondence to: Melánia Babincová, Professor of Biophysics, Department of Nuclear Physics and Biophysics, Faculty of Mathematics, Physics and Informatics, Comenius University, Mlynská dolina F1, 84248 Bratislava, Slovakia. Tel: +42 1904180025, e-mail: babincova@fmph.uniba.sk

Key Words: Glioblastoma, magnetic nanoparticles, human serum albumin, hyperthermia, etoposide, chemotherapy. high resistance to radiotherapy and chemotherapy $(1,2)$. The main reasons for the poor prognosis of GBM are diagnosis at a late stage and lack of efficient therapies. The standard therapeutic protocols for the treatment of GBM have only limited benefits and provide a median survival of patients of no longer than 15 months (3).

Etoposide (VP-16) is a semi-synthetic derivative of a naturally occurring antibiotic, podophyllotoxin (Figure 1A), introduced into cancer clinical trials in 1971, and U.S. Food and Drug Administration-approved since 1983 (4-6). It inhibits topoisomerase II re-ligation of cleaved DNA molecules, resulting in the accumulation of double-strand DNA breaks. This leads to late $S$ and $\mathrm{G}_{2}$ cell-cycle arrest. Previous studies have reported that etoposide is effective against glioma cell lines and it is currently widely used in the treatment of lung and ovarian cancer, as well as recurrent childhood brain tumors. Effective against GBM at high doses, etoposide leads to toxic side-effects such as nausea, weight loss, alopecia, myelosuppression with leucopenia, and thrombocytopenia $(7,8)$.

Nanostructures are nowadays widely used in experimental and clinical medicine applications as diagnostic, imaging, and therapeutic agents. Magnetic nanoparticles (MNPs) exposed to an external alternating magnetic field (AMF) are heated through either hysteresis loss or relaxation loss depending on their size and properties. In magnetic hyperthermia, MNPs act as nanoheaters through energy conversion from external AMF into heat. Because cancer cells are killed at a temperature of about $43^{\circ} \mathrm{C}$, whereas normal cells survive at these higher temperatures, magnetically mediated hyperthermia induced by AMF can be used to selectively destroy cancer cells in which magnetic particles have accumulated.

Thermotherapy involving the use of an AMF in conjunction with MNPs has proven to be an effective method 
for treating patients with GBM. Initial tests have shown that MNPs have minimal toxicities for patients, although further testing must be performed to confirm these findings (9). Much like other methods that are used to combat GBM, MNPs do not serve as a cure on their own; they have been shown to be most effective when used as a combination with other treatment modalities, for example combining fractionated radiotherapy with thermotherapy has been shown to have a survival advantage in patients with relapsed GBM (10).

Since the report by Zimmermann and Pilwat (11), MNPs have attracted attention not only as nanoheaters for cancer therapy (hyperthermia) but also because of their potential as contrast agents for magnetic resonance imaging (MRI), and magnetic drug targeting (12-18).

Our aim in this study was to demonstrate effectivity of MNPs for integrated cancer therapy of the glioblastoma cell line U87. For these purposes, we prepared MNPs functionalized with human serum albumin (HSA) (19-21) embedded with etoposide.

\section{Materials and Methods}

Preparation of HSA immobilized MNPs. MNPs were prepared by a modified co-precipitation method (19) in the presence of HSA which facilitated the in situ immobilization of crystallized MNPs by the protein. A volume of $180 \mathrm{ml}$ of deoxygenated water with $1 \mathrm{~g}$ of HSA (Sigma, St. Louis, MO, USA) and $3 \mathrm{ml}$ of ammonium hydroxide $(30 \%, \mathrm{w} / \mathrm{v})$ under constant stirring and nitrogen flow, 20 $\mathrm{ml}$ of iron salts $\left(1.08 \mathrm{~g}\right.$ of $\mathrm{FeCl}_{3} \bullet 6 \mathrm{H}_{2} \mathrm{O}$ and $0.4 \mathrm{~g}$ of $\mathrm{FeCl}_{2} \bullet 4 \mathrm{H}_{2} \mathrm{O}$; Centralchem, Bratislava, Slovakia) was added dropwise at room temperature. The reaction mixture was then heated and processed at $70^{\circ} \mathrm{C}$ for another $15 \mathrm{~min}$. The resulting products were dialyzed in phosphate-buffered saline $(20 \mathrm{mM}, \mathrm{pH} 7.4)$ to remove excess ammonium hydroxide and residual iron salts. Five milligrams of etoposide (BioVision, Inc., San Francisco, CA, USA) was dissolved in $1 \mathrm{ml}$ of dimethylsulfoxide (Centralchem) and the solution was dropwise added to the desired amount of MNP-HSA. The mixture was stirred at $900 \mathrm{rpm}$ for $4 \mathrm{~h}$. Unloaded etoposide was removed by ultrafiltration (MW cutoff: 10,000 Da; Millipore, Merck, Darmstadt, Germany) to obtain final stock of MNP-HSA-ETO (Figure 1B).

Etoposide release under AMF. The percentage of etoposide released due to AMF heating was obtained from the total amount (WT) of added etoposide in a MNP-HSA-ETO sample and the amount of released etoposide $\left(\mathrm{W}_{\mathrm{R}}\right)$ in supernatant after centrifugation $(10000 \times$ $g, 30 \mathrm{~min})$ using the formula $\left(\mathrm{W}_{\mathrm{R}} / \mathrm{WT}\right) \times 100 \%$. The concentration of etoposide was quantified using a calibration curve obtained from absorbance measurement using UV MINI 1240 UV-VIS spectrophotometer (Shimadzu, Kyoto, Japan).

Cell culture. U87-MG human glioblastoma cell lines were acquired from the American Type Culture Collection (Manassas, VA, USA). Cells were grown in Dulbecco's modified Eagle's medium (DMEM) with Glutamax (ThermoFisher Scientific, Waltham, MA, USA) supplemented with $10 \%$ fetal bovine serum (FBS; Gibco, Waltham, MA, USA) and 1\% 5,000 U/ml Penn/Strep (ThermoFisher Scientific) in 96-well plates (Corning Inc., Corning, NY, USA) in a humidified atmosphere of $95 \%$ air and $5 \% \mathrm{CO}_{2}$ at $37^{\circ} \mathrm{C}$. The cells were seeded at a density of $5 \times 10^{3}$ cells/well, $24 \mathrm{~h}$ before experiments.

Cell viability assay. The in vitro cell viability was performed using a modified 3-(4,5-dimethylthiazol-2-yl)-2,5-diphenyl tetrazolium bromide (MTT) assay (22). (Sigma, St. Louis, MO, USA) U87-MG cells were plated (5000 in $100 \mu \mathrm{l}$ of medium) into each well of a 96-well plate and incubated for $24 \mathrm{~h}$. Fifty microliters of etoposide, MNPs, or MNPHSA-ETO suspended in medium were added and incubated for $24 \mathrm{~h}$. The supernatant was carefully removed and $10 \mu \mathrm{l}$ of media and $20 \mu \mathrm{l}$ of a $5 \mathrm{mg} / \mathrm{ml}$ MTT solution added and plates incubated for a further 3 h. As a control, $150 \mu \mathrm{l}$ of PBS at pH 7.4 was added to cells in eight of the wells. The supernatant in each well was aspirated and $150 \mu \mathrm{l}$ of dimethyl sulfoxide was added to solubilize the cells and MTT crystals. After $1 \mathrm{~h}$ of shaking on an Eppendorf Thermomixer at $37^{\circ} \mathrm{C}$ and 400 rpm to dissolve all crystals, the blue color was read in a multiwell scanning spectrophotometer at $540 \mathrm{~nm}$ using a microplate reader (Multiskan GO spectrophotometer; ThermoFisher Scientific). Cell viability was quantified by the relative absorbance of the drug-treated wells to the control wells without drug treatment. The cell viability was calculated by comparing the sample absorption to the one of the control cells, which was by definition $100 \%$.

Setup for application of electromagnetic hyperthermia. AMF with a frequency of $3.5 \mathrm{MHz}$ and an amplitude of $1.2 \mathrm{kA} \mathrm{m}^{-1}$ was generated using a $3.5 \mathrm{MHz}$ radiofrequency generator (model GV6A; ZEZ a.s., Rychnov nad Nisou, Czech Republic) with a power dissipation of $6 \mathrm{~kW}$. The coil-shaped and water-cooled antenna with a diameter of $15 \mathrm{~cm}$ was made of three copper windings, connected to a water-cooled resonance circuit which produced the electromagnetic field. Magnetic field amplitude and frequency produced in our equipment were within the safety range (23). For the evaluation of the effect of hyperthermia, U87-MG glioma cells were seeded on $35 \mathrm{~mm}$ Petri dishes $\left(2 \times 10^{5}\right.$ in $3 \mathrm{ml}$ of growth medium per dish). Prior to AMF heating, samples and controls were incubated at $37^{\circ} \mathrm{C}$ for $15 \mathrm{~min}$ to stabilize temperature. During the experiments samples were placed in the center of the induction coil for the desired time. To measure the temperature changes over time during exposure to the AMF, we used an optic fiber thermometer FOB101 with automatic registration (Omega Engineering, Norwalk, CT, USA). After the heat treatment, the suspension of U87-MG glioma cells was diluted to $4.8 \mathrm{ml}$ media and seeded in a $96-$ well plate at a density of $5 \times 10^{3}$ cells/well.

Statistical analysis. The experiments were performed at least five times. Data are expressed as the mean \pm standard deviation (SD). Statistical correlation of data was checked for significance by ANOVA and Student's $t$-test. Values of $p<0.05$ were considered to indicate a statistically significant difference.

\section{Results and Discussion}

In the present study, we firstly tested the effect of free etoposide and evaluated its toxicity towards U87-MG glioma cell in vitro using MTT assay. The quantification of etoposide concentration was based on the strong absorption maximum of this molecule at $480 \mathrm{~nm}$. We, therefore, measured etoposide absorbance at increasing concentrations (Figure 2). We found 

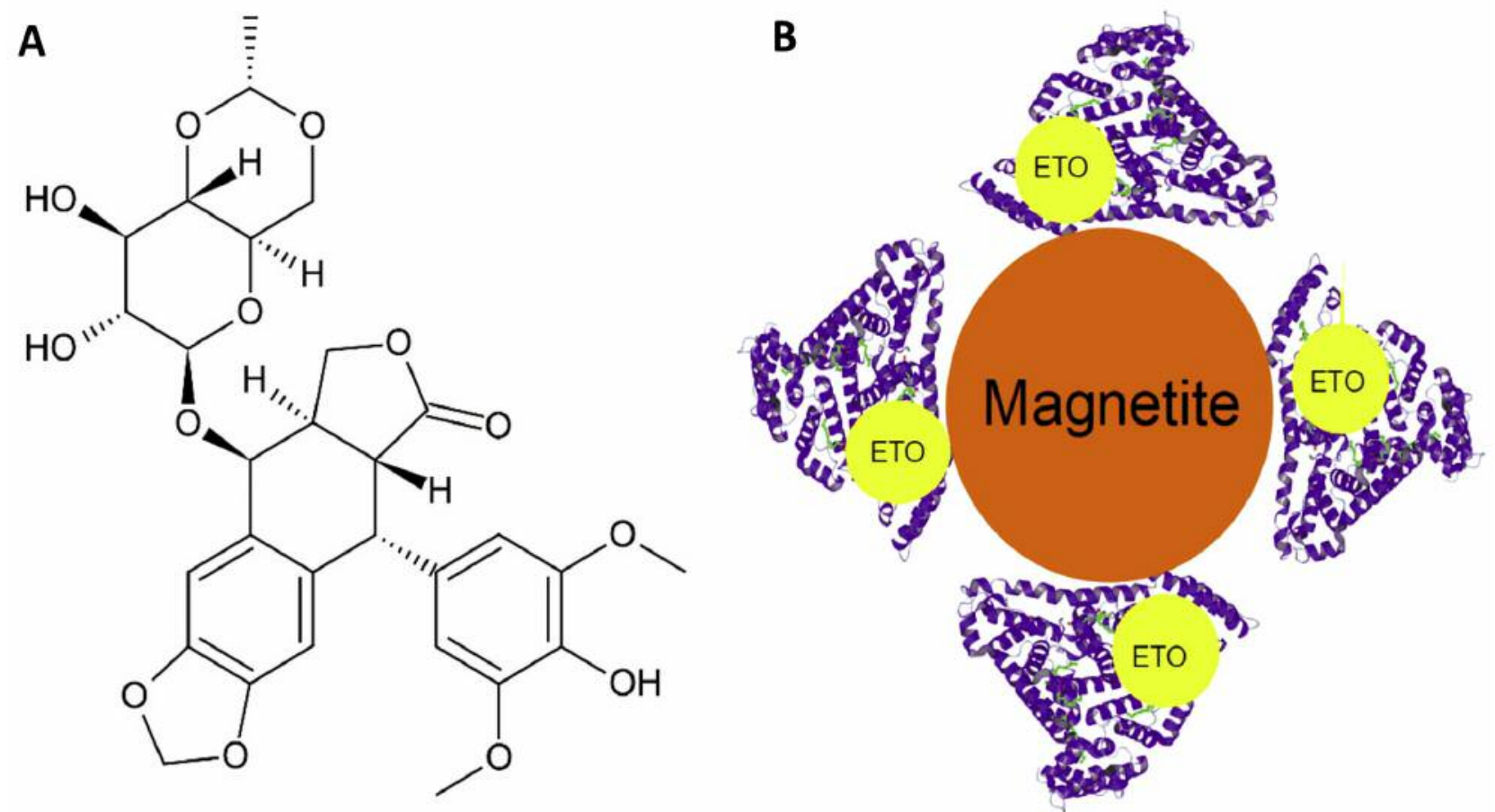

Figure 1. A: Chemical structure of etoposide. B: Schematic illustration of magnetic nanoheaters with human serum albumin carrying co-embedded etoposide (ETO).

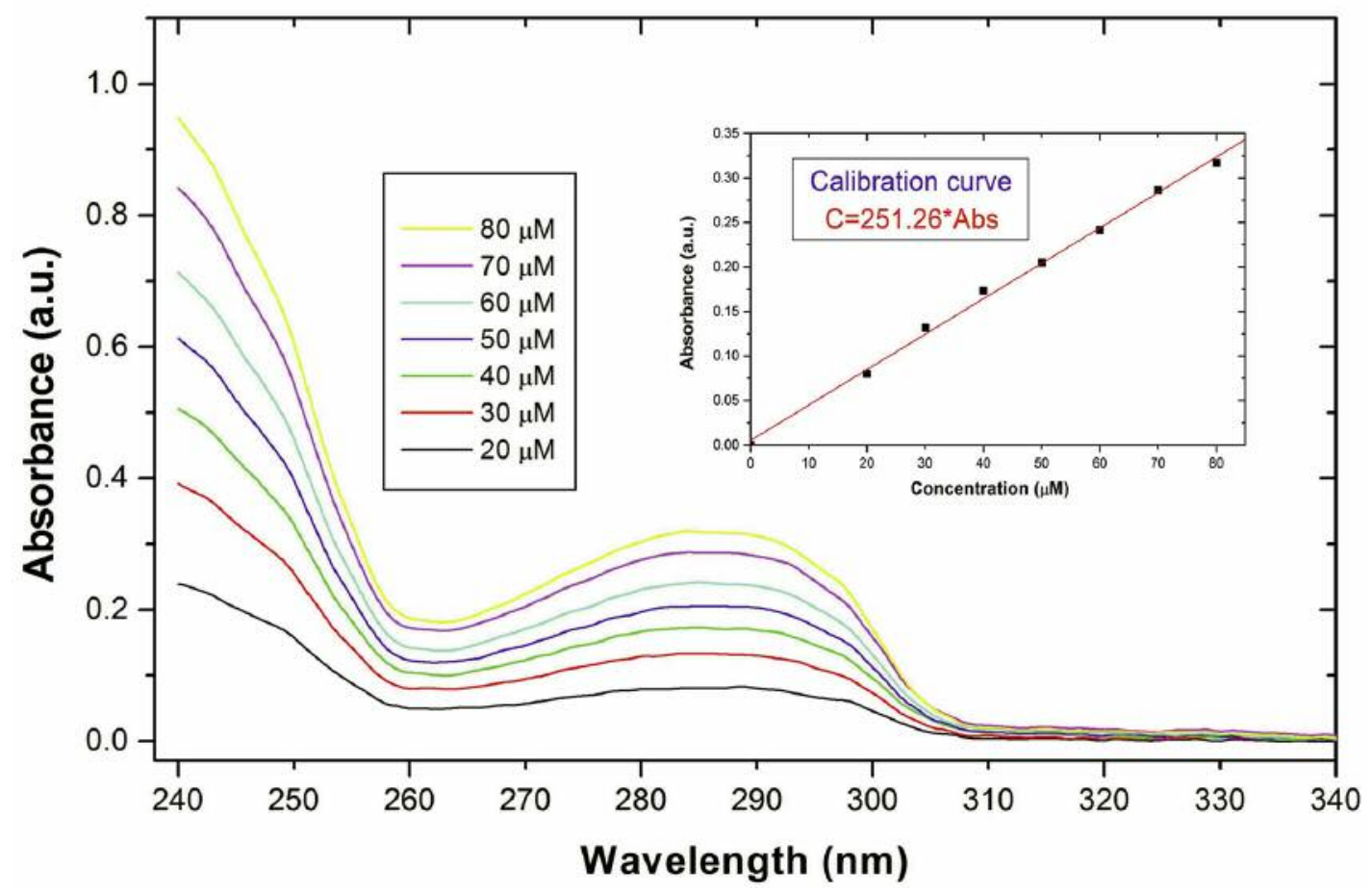

Figure 2. UV absorption spectra of etoposide for samples with increasing concentration. Inset: Calibration curve of etoposide used for its quantification. 


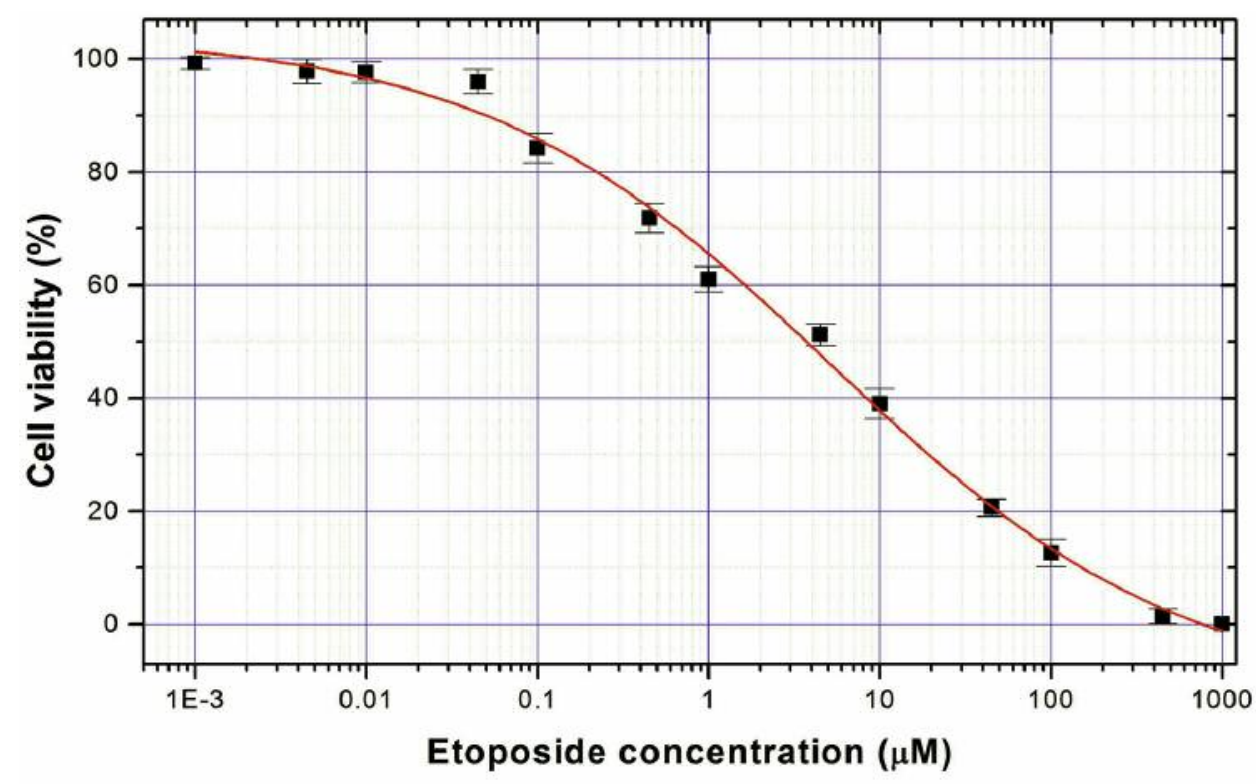

Figure 3. Viability of U87-MG glioma cells used for the determination of half-maximal inhibitory concentration of etoposide. Results are means $\pm S D$ from five independent experiments.

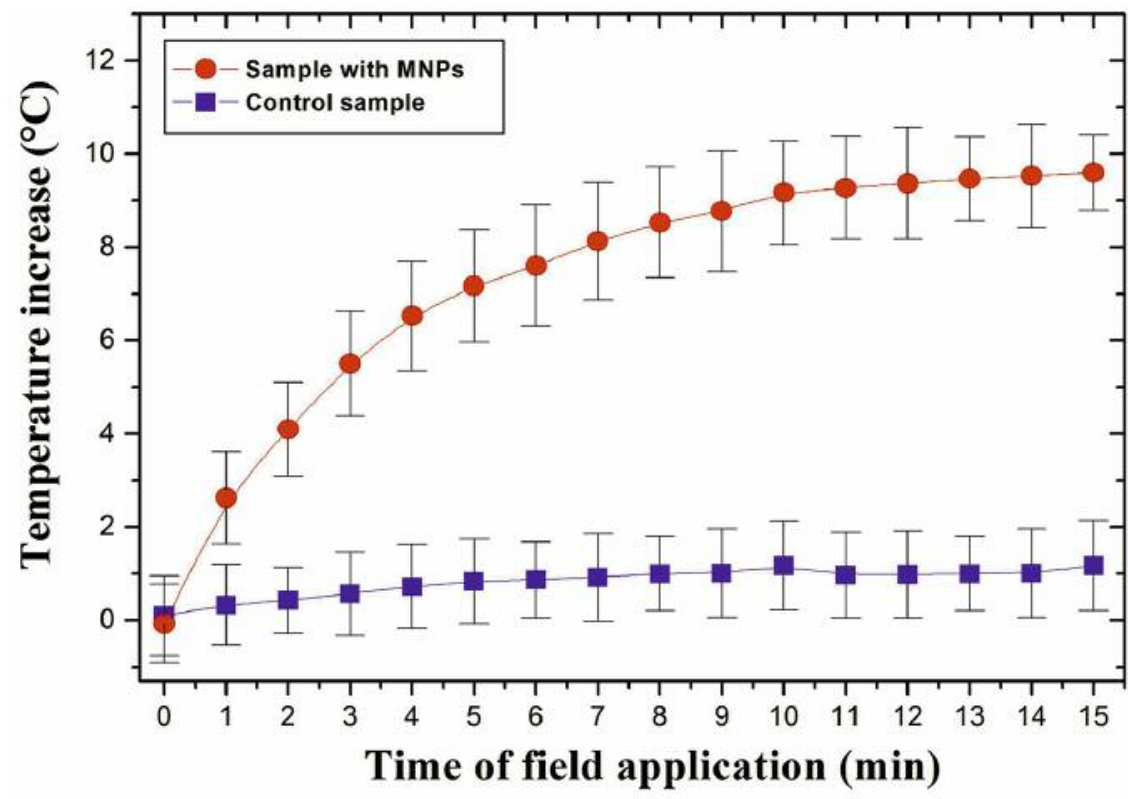

Figure 4. Increase of temperature of human serum albumin magnetic nanoparticles (MNPs) (concentration of $\mathrm{Fe}=5 \mathrm{mg} / \mathrm{ml}$ ) in an alternating magnetic field as a function of time. Results are means $\pm S D$ from five independent experiments.

a linear dependence of the absorbance (Abs) on concentration (C) of etoposide (calibration curve) explicitly given by the equation $\mathrm{C}=251.26 \times \mathrm{Abs}$, which we used for the etoposide determination. From Figure 3, the half-maximal inhibitory concentration $\left(\mathrm{IC}_{50}\right)$ of etoposide was found to be $2.9 \mu \mathrm{M}$.
Embedded MNPs in MNP-HSA complex served as nanoheaters, therefore we further performed heating experiments in an AMF to test their ability to generate heat. As shown in Figure 4, relatively rapid temperature increases were observed over the first $8 \mathrm{~min}$. After $15 \mathrm{~min}$, a slower 


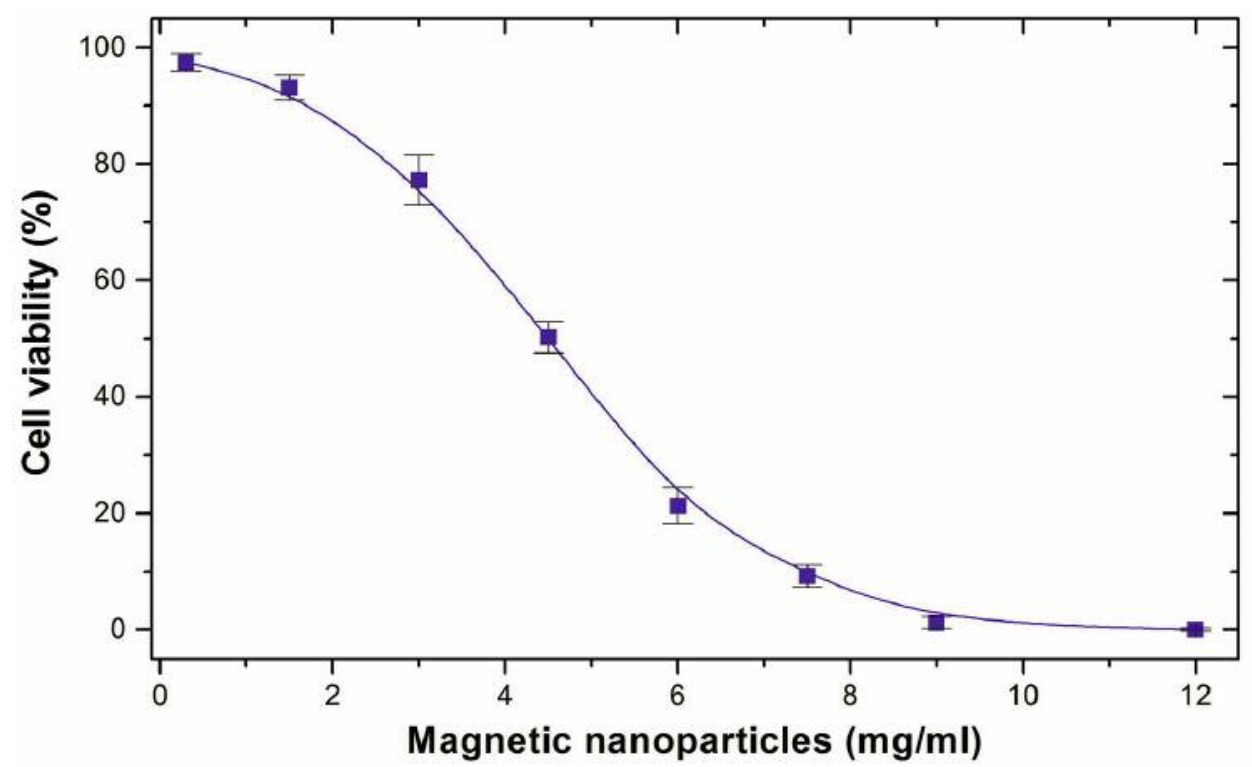

Figure 5. Influence of increasing concentration of human serum albumin magnetic nanoparticles on the viabilty of U87-MG glioma cells after 15 min exposure to an alternating magnetic field. Results are means $\pm S D$ from five independent experiments.

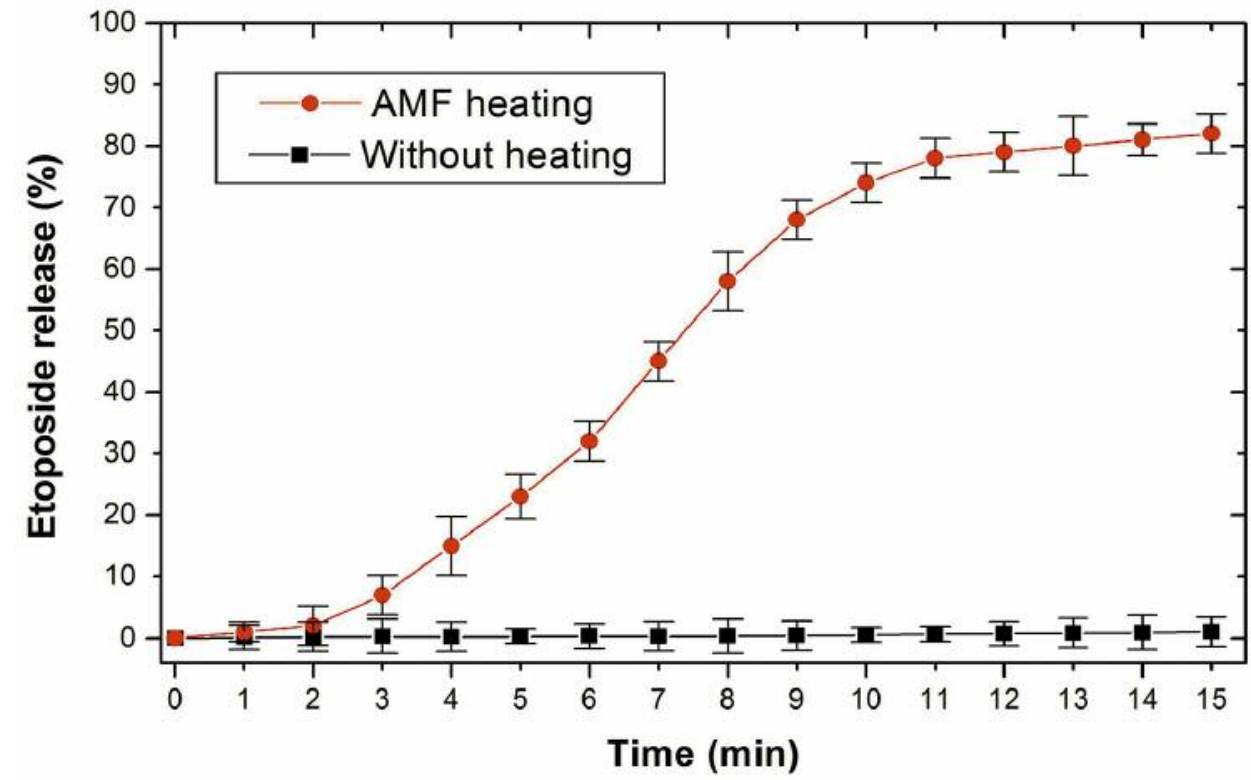

Figure 6. An alternating magnetic field (AMF) induced release of etoposide from etoposide-carrying human serum albumin-embedded magnetic nanoparticles according to irradiation time. Results are means \pm SD from five independent experiments.

rate of increase of temperature was established. These results indicate that the magnetite-based nanoheaters can sufficiently elevate the temperature of the environment to induce hyperthermia. Efficient heat dissipation can be attributed to the superparamagnetic nature of MNPs and the Brown and Néel relaxation effect.
For hyperthermia applications, the temperature of cancerous tissue must reach $42-45^{\circ} \mathrm{C}$ for effective therapy, and this is easily attainable using these MNPs. To test the effect of MNP-mediated AMF-induced hyperthermia on cell cultures, we irradiated glioma U87 cell culture containing an increasing amount of MNP-HSA. The concentration of Fe in 


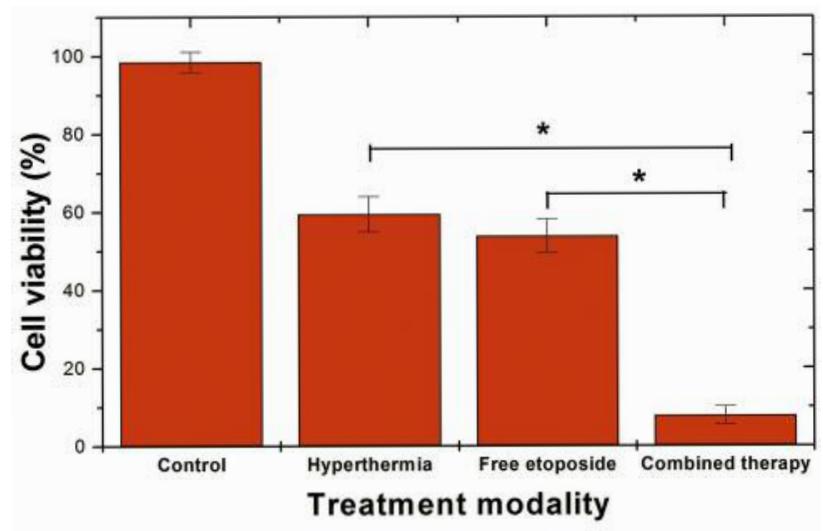

Figure 7. Comparison of viability of control U87-MG glioma cells with cells treated using hyperthermia mediated by human serum albumin magnetic nanoparticles in an alternating magnetic field, cells treated with pure etoposide, and combined treatment using etoposide-carrying human serum albumin magnetic nanoparticles in an alternating magnetic field. Results are means $\pm S D$ from five independent experiments. *Significantly different at $p<0.05$.

MNPs was $0-15 \mathrm{mg} / \mathrm{ml}$. Viability of cells was assessed again using MTT assay. The results of this viability testing for U87-MG cells are shown in Figure 5; 50\% viability was achieved using MNP-HSA with $4.5 \mathrm{mg} / \mathrm{ml}$ of Fe. These results further show the suitability of these nanostructures for anticancer hyperthermic therapy.

For even more efficient anticancer applications of nanoparticles, where we wanted to integrate both hyperthermia and chemotherapy for these purposes, we prepared etoposide-containing MNP-HSA nanostructures. The profile of controlled drug release from MNP-HSA-ETO (concentration of $\mathrm{Fe}=5 \mathrm{mg} / \mathrm{ml}$ ) was evaluated in the presence of an AMF and at physiological temperature $\left(37^{\circ} \mathrm{C}\right)$. Etoposide release from MNP-HSA-ETO under an AMF was $\sim 20 \%$ after 5 min of exposure, and increased to $\sim 80 \%$ after $10 \mathrm{~min}$ (Figure 6). The heat produced from the magnetic nanoheaters increased the temperature of MNP-HSA-ETO and probably induced conformational change due to the reversible denaturation of albumin, triggering the release of the encapsulated drug. It is important that the initial burst release, common for adsorptive binding of drugs to nanoparticles, is avoided. Measurement of drug release at physiological temperature $\left(37^{\circ} \mathrm{C}\right)$ after $15 \mathrm{~min}$ was lower than $0.5 \%$ of the encapsulated etoposide.

MNPs are also suitable for combined cancer chemotherapy and hyperthermia (24-28). The effect of AMF-induced MNP-HSA-ETO hyperthermia accompanied by etoposide release can be determined through the assessment of cell viability. For clinical applications it is important to demonstrate synergistic combinatorial effect.
In vitro hyperthermia experiments were performed under AMF magnetic field on rat U87-MG glioma cells for 15 min, with MNP-HSA-ETO containing $3.6 \mathrm{mg} / \mathrm{ml}$ of $\mathrm{Fe}$, with and without $3 \mu \mathrm{M}$ etoposide. Figure 7 shows the relative number of U87-MG cells $24 \mathrm{~h}$ after different treatment modalities. For electromagnetic hyperthermia treatment (magnetic field was applied for $15 \mathrm{~min}$ ) with MNP-HSA with $3.6 \mathrm{mg} \mathrm{Fe} / \mathrm{ml}$, the viability was $59.4 \%$. For $3 \mu \mathrm{M}$ free etoposide without nanoparticles, the relative cell number was $53.8 \%$. When the electromagnetic hyperthermia treatment was performed with MNP-HSA-ETO (containing the same concentration of $\mathrm{Fe}$, as well as of etoposide), the relative cell number decreased to only $7.8 \%$, therefore in our study, integration of hyperthermia and chemotherapy killed $92.2 \%$ of U87-MG cells. The combined effect of treatments was quantified according to (29) and the combinatorial therapy was found to be synergistic. Moreover, the increased cytotoxicity to cancerous cells accompanied by a reduction of toxic effects on noncancerous cells is considered a promising improvement in the therapeutic efficacy when etoposide is entrapped in MNP-HSA-ETO. Such a feature may be ascribed to a combination of higher etoposide delivery to cancerous cells and faster release of etoposide from MNP-HSA-ETO within the cells. The drug efflux from cancerous cells, resulting in cancer resistance, could be avoided by nanoparticulation of drugs, as they enter cells via endocytotic pathway. Moreover, the metabolic activity of cancerous cells, which is usually higher than that of non-cancerous cells, may create a more acidic environment inside the cancerous cells, resulting in MNP-HSA-ETO degradation, and consequently more etoposide release and greater cytotoxicity.

As has been demonstrated in clinical studies (30-35), $6 \%$ of etoposide is bound to HSA, heavily influencing its pharmacokinetics. In this study, we made this shortcoming an advantage, similar to the example of Abraxane, the noncovalent complex of HSA with paclitaxel; this first FDAapproved nanoparticulate drug formula has been proven to have better pharmacokinetics than paclitaxel alone and to be superior to the latter for tumor therapeutics (36).

Most of the studies in vivo use direct injection of MNPs into the center of tumors. A more elegant approach is to use high-gradient external magnets for the targeting of MNPs to the tumors $(12,13)$, thereby avoiding adverse side-effects. Another possibility found recently (18) is that MNPs packaged into exosomes, which are efficiently endocytosed by tumor cells, facilitate targeted tumor cell ablation via magnetically induced hyperthermia.

Glioblastoma remains the most difficult-to-treat malignant brain tumor due to its resistance to standard therapies and its invasive growth into the normal brain. Multifunctional MNPs are a promising nanoplatform for the imaging and treatment of malignant brain tumors. The subject of our 
study was synthesis and applications of novel etoposidecarrying HSA immobilized MNPs in order to increase the amount of drug in tumors, mediate electromagnetic hyperthermia and controlled drug release, and eliminate adverse effects on healthy tissues. Moreover, as was recently found (37), magnetic hyperthermia using MNPs and AMF can increase the permeability of the blood-brain barrier without perturbing other brain cells.

Our plan for the future is to study in vivo magnetic drug targeting combined with AMF-controlled release and hyperthermia using these MNPs, which may have many important clinical applications.

\section{Conflicts of Interest}

The Authors report no conflict of interest in regard to this study.

\section{Acknowledgements}

This work was supported by a grant of Slovak grant agency VEGA 1/0810/18 and APVV-16-0600.

\section{References}

1 De Felice F, Musio D, Cassese R, Gravina GL and Tombolini V: New approaches in glioblastoma multiforme: The potential role of immune-check point inhibitors. Current Cancer Drug Targets 17: 282-289, 2017.

2 Louis DN, Ohgaki H, Wiestler OD, Cavenee WK, Burger PC,Jouvet A, Scheithauer BW and Kleihues P: The 2007 WHO Classification of Tumours of the Central Nervous System. Acta Neuropathol 114: 97-109, 2007.

3 Polivka J Jr., Polivka J. Holubec L, Kubikova T, Priban V, Hes $\mathrm{O}$, Pivovarcikova $\mathrm{K}$ and Treskova I: Advances in experimental targeted therapy and immunotherapy for patients with glioblastoma multiforme. Anticancer Res 37: 21-33, 2017.

4 Baldwin EL and Osheroff N: Etoposide, topoisomerase II and cancer: Curr Med Chem Anticancer Agents 5: 363-372, 2005.

5 Jeremic B, Grujicic D, Jevremovic S, Stanisavljevic B, Milojevic L, Djuric L and Mitajovic L: Carboplatin and etoposide chemotherapy regimen for recurrent malignant glioma: a phase II study. J Clin Oncol 10: 1074-1077, 1992.

6 Elhag R, Mazzio EA, Soliman KFA: The effect of silibinin in enhancing toxicity of temozolomide and etoposide in p53 and PTEN-mutated resistant glioma cell lines. Anticancer Res 35: 1263-1270, 2015.

7 Nakagawa T, Kubota T, Ido K, Sakuma T and Matsuda K: The combined effects of multiple chemotherapeutic agents for malignant glioma cells. J Neuro-Oncol 84: 31-37, 2007.

8 Luciano R, Battafarano G, Saracino R, Rossi M, Perrotta A, Manco M, Muraca M and Del Fattore A: New perspectives in glioblastoma: Nanoparticle-based approaches. Curr Cancer Drug Targets 17: 203-220, 2017.

9 Mahmoudi M, Hofmann H, Rothen-Rutishauser B and Petri-Fink A: Assessing the in vitro and in vivo toxicity of superparamagnetic iron oxide nanoparticles. Chem Rev 112: 2323-2338, 2012.
10 Maier-Hauff K, Ulrich F, Nestler D, Niehoff H, Wust P, Thiesen B, Orawa H, Budach V and Jordan A: Efficacy and safety of intratumoral thermotherapy using magnetic iron-oxide nanoparticles combined with external beam radiotherapy on patients with recurrent glioblastoma multiforme. J Neurooncol 103: 317-324, 2011.

11 Zimmermann U and Pilwat G: Organ specific application of drugs by means of cellular capsule systems. Z Naturforsch Sect C J Biosci 31: 732-736, 1976.

12 Babinec P, Krafč́́k A, Babincová M and Rosenecker J: Dynamics of magnetic particles in cylindrical Halbach array: Implications for magnetic cell separation and drug targeting. Med Biol Eng Comput 48: 745-753, 2010.

13 Babincová M, Altanerová , Lampert M, Altaner C, Machová E, Šrámka $\mathrm{M}$ and Babinec $\mathrm{P}$ : Site-specific in vivo targeting of magnetoliposomes using externally applied magnetic field. Z Naturforsch Sect C J Biosci 55: 78-281, 2000.

14 Babincová M, Cicmanec P, Altanerova V, Altaner C and Babinec $\mathrm{P}$ : AC magnetic field controlled drug release from magnetoliposomes: Design of a method for site-specific chemotherapy. Bioelectrochemistry 55: 17-19, 2002.

15 Babincová, M, Altanerova V, Altaner C, Bergemann C and Babinec $\mathrm{P}$ : In vitro analysis of cisplatin functionalized magnetic nanoparticles in combined cancer chemotherapy and electromagnetic hyperthermia. IEEE Transact Nanobiosci 7: 15-19, 2008.

16 Babincová M, Babincová N, Durdík S, Bergemann C and Sourivong P: Silencing by blasting: Combination of laser pulseinduced stress waves and magnetophoresis for siRNA delivery. Laser Phys Lett 13: 065601, 2016.

17 Durdík S, Krafčík A, Babincová M and Babinec P: Conceptual design of integrated microfluidic system for magnetic cell separation, electroporation and transfection. Phys Med 29: 562$567,2013$.

18 Altanerova U, Babincova M, Babinec P, Benejova K, Jakubechova J, Altanerova V, Zduriencikova M, Repiska V and Altaner C: Human mesenchymal stem cell-derived iron oxide exosomes allow targeted ablation of tumor cells via magnetic hyperthermia. Int J Nanomed 12: 7923-7936, 2017.

19 Nosrati H, Sefidi N, Sharafi A, Danafar H and Kheiri Manjili H: Bovine serum albumin (BSA)-coated iron oxide magnetic nanoparticles as biocompatible carriers for curcumin-anticancer drug. Bioorg Chem 76: 501-509, 2018.

20 Chen S, Liang Q, Liu E, Yu Z, Sun L, Ye J, Shin M-, Wang J and He H: Curcumin/sunitinib co-loaded BSA-stabilized SPIOs for synergistic combination therapy for breast cancer. J Mater Chem B 5: 4060-4072, 2017.

21 Pöttler M, Hofmann S, Dürr S, Unterweger H, Wiest I, Zaloga J, Alexiou C, Jeschke U, Janko C: Effect of BSA-coated superparamagnetic iron oxide nanoparticles on granulosa cells. Anticancer Res 36: 3147-3154, 2016.

22 Häfeli OU, Riffle JS, Harris-Shekhawat 1, CarmichaelBaranauskas A, Mark F, Dalley JP and Bardenstein D: Cell uptake and in vitro toxicity of magnetic nanoparticles suitable for drug delivery. Mol Pharm 6: 1417-1428, 2009.

23 Hergt $\mathrm{R}$ and Dutz S: Magnetic particle hyperthermia biophysical limitations of a visionary tumour therapy. J Magn Magn Mater 311: 187-192, 2007.

24 Titsworth WL, Murad GJA, Hoh BL and Rahman M: Fighting fire with fire: The revival of thermotherapy for gliomas. Anticancer Res 34: 565-574, 2014. 
25 Istomin YD, Zhavrid EA, Sachivko NV, Alexandrova EN and Pocheshinsky PV: The effect of cytostatics and hyperthermia on RAJI human lymphoma cells. Exp Oncol 33: 19-23, 2011.

26 Istomin YP, Zhavrid EA, Alexandrova EN, Sergeyeva OP and Petrovich SV: Dose enhancement effect of anticaner drugs associated with increased temperature in vitro. Exp Oncol 30: 56-59, 2008.

27 Cohen JD, Robins HI and Schmitt CL: Tumoricidal interactions of hyperthermia with carboplatin, cisplatin and etoposide. Cancer Lett 44: 205-210, 1989.

28 Kulshrestha P, Gogoi M, Bahadur D and Banerjee R: In vitro application of paclitaxel loaded magnetoliposomes for combined chemotherapy and hyperthermia. Colloids Surf B Biointerfaces 96: 1-7, 2012.

29 Valeriote F and Lin HS: Synergistic interaction of anticancer agents: A cellular perspective. Cancer Chemother Rep 59: 895900, 1975.

30 Fleming RA, Evans WE, Arbuck SG and Stewart CF: Factors affecting in vitro protein binding of etoposide in humans. J Pharm Sci 81: 259-264, 1992.

31 Wang Z-, Ho JX, Ruble JR, Rose J, Rüker F, Ellenburg M, Murphy R, Click J, Soistman E, Wilkerson L and Carter DC: Structural studies of several clinically important oncology drugs in complex with human serum albumin. Biochim Biophys Acta Gen Subj 1830: 5356-5374, 2013.
32 Ohnuma T, Ohnuma T, Kavy S, Bhardwaj S and Holland JF: Interaction of human serum albumin with anticancer agents in vitro. Br J Cancer 41: 602-608, 1980.

33 Yang Z, Cheng Y, Zhou T and Xu F: Excessive human serum albumin might weaken anticancer effect of cisplatin and etoposide in vitro study. Int J Clin Exp Med 9: 13384-13393, 2016.

34 Bilmin K, Kopczynska B and Grieb P: Influence of serum and albumin on the in vitro anandamide cytotoxicity toward C6 glioma cells assessed by the MTT cell viability assay: Implications for the methodology of the MTT tests. Folia Neuropathol 51: 44-50, 2013.

$35 \mathrm{Xu}$ WZ, Li F, Xu ZK, Chen X, Sun B, Cao JW and Liu YG: Preoperative albumin-to-globulin ratio and prognostic nutrition index predict prognosis for glioblastoma. Onco Targets Ther 10: 725-733, 2017.

36 Gradishar WJ: Albumin-bound paclitaxel: a next-generation taxane. Expert Opin Pharmacother 7: 1041-1053, 2006.

37 Tabatabaei SN, Girouard H, Carret AS and Martel S: Remote control of the permeability of the blood-brain barrier by magnetic heating of nanoparticles: A proof of concept for brain drug delivery. J Control Release 206: 49-57, 2015.

Received January 26, 2018

Revised March 9, 2018

Accepted March 14, 2018 